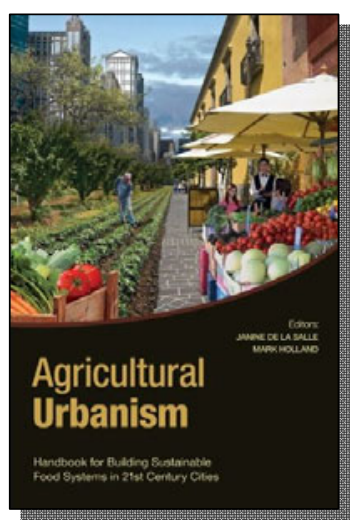

\title{
Planning urban foodscapes
}

\author{
Book Review: Agricultural Urbanism: Handbook for \\ Building Sustainable Food Systems in 21st Century Cities, \\ edited by Janine de la Salle and Mark Holland
}

Review by Nevin Cohen, The New School

De la Salle, J., \& Holland, M. (Editors). (2010). Agricultural Urbanism: Handbook for building sustainable food systems in 21st century cities. Winnipeg, Manitoba, Canada: Green Frigate Books.

Published online 30 November 2011

Citation: Cohen, N. (2011). Planning urban foodscapes [review of the book Agricultural Urbanism: Handbook for Building Sustainable Food Systems in 21st Century Cities, edited by Janine de la Salle and Mark Holland]. Journal of Agriculture, Food Systems, and Community Development, 2(1), 319-321. http://dx.doi.org/10.5304/jafscd.2011.021.016

Copyright (C) 2011 by New Leaf Associates, Inc.

$\mathrm{O}$ ne of the most exciting new areas of planning and development involves innovative strategies to reintegrate food production and distribution into our communities. Agricultural Urbanism, edited by senior planners at HB Lanarc, a Vancouverbased planning and design firm, is a collection of planning, policy, and design concepts to do just that. The book outlines a program - a manifesto, really — for "building a place around food" (p. 9). This requires rethinking the role of food in cities, transforming the messy elements of food production and processing functions that have been relegated to the "back of the house" to the "front of the house," and making food systems visible in communities so that people become reconnected to the sources of their food and better understand the nature of food production. In describing the contours of agricultural urbanism, the authors ambitiously discuss the whole gamut of the food system, including food access, the food economy, infrastructure, education, place-making, policy, and environmental protection.

Urban planners and landscape architects will recognize many of the ideas in Agricultural Urbanism from the works of William H. Whyte, Donald Appleyard, Jahn Gehl, and more recently, Andre Viljoen. Designing eating and drinking opportunities into the streetscape, integrating productive edible landscapes, using stormwater for agricultural irrigation, and designing interpretive signage and other features to connect people to food at the streetscape, are all concepts that urban theorists have written about for decades. The concepts of agricultural urbanism have been implemented in various contexts ranging from festival retailing projects to green infrastructure plans. Cities like Seattle have integrated urban agriculture into a wide range of projects; Toronto is experimenting with neighborhood food production hubs for 
economic development; and New York is innovating with rooftop farming. The authors have drawn on these precedents, added their professional experiences, and wrapped the ideas together into a framework that is easy to understand and apply, much like the principles of New Urbanism that define mixed-use, walkable communities that embody traditional neighborhood design.

In fact, Agricultural Urbanism uses the New Urbanist concept of the transect, or the gradient from rural to urban, to identify appropriate forms and scales of food production systems that can be integrated into the landscape, from the most rural communities to dense downtowns. At the rural edge, this might take the form of new clustered residential, commercial, and processing facilities that enable farmers to interact, more efficiently share equipment and facilities, and improve their productivity. In suburbia, agricultural urbanism might involve the integration of residential subdivisions and small-scale farms, such as Prairie Crossing, the suburban Chicago residential development that includes 40 acres of farmland. ${ }^{1}$ At the urban end of the transect, in center cities filled with high rises, agricultural urbanism might include networks of window-boxes, community gardens, and rooftop farms that enable apartment dwellers to grow some of their own food.

In presenting a broad range of ideas, Agricultural Urbanism provides policymakers and planners with a framework for thinking comprehensively and holistically about food in their day-to-day duties. The book provides a rich conceptual overview, though practitioners will need to consult other resources for the financial, technical, and logistical details needed to design and implement specific projects. For example, a statement that the production of local foods reduces transportation-related energy use (p. 39) fails to explain that the energy efficiency of food production and transportation depends on much more than proximity, as a recent

${ }^{1}$ Cohen, N. (2007). The Suburban Farm: An innovative model for civic agriculture. Urban Agriculture Magazine, 19, 55-57. Available at http://www.ruaf.org/book/export/html/101
USDA report has shown. ${ }^{2} \mathrm{~A}$ recommendation to retrofit industrial buildings to support rooftop farming (p. 42) may be overstating the possibilities given the substantial costs of reinforcing roofs, installing growing media, and the limitations of growing food on windy, dry, hot rooftops with shallow soil. A suggestion based on a case study of a particular Vancouver urban farmer that urbanites have "access to cheap land" (p. 165) does not apply to those in built-out cities. The idea that more "benign growing conditions... with fewer wild pests and built-in wind protection" (p. 166) minimizes the substantial challenges of urban agriculture, from desiccating wind on rooftops to relatively high water costs compared to rural farmers. More careful analysis and better attention to source material would make the arguments in the book much more compelling.

Some of those details are, in fact, critical for building support for agricultural urbanism. Without that level of detail, many policymakers and citizens will remain skeptical that food production and development fit together, viewing the incorporation of farms in subdivisions as only marginally better than the golf courses that anchor many suburban communities. The need for better data about the benefits of agricultural urbanism, lessons learned from existing projects, and the critical assessment of its limits would help to build support for these projects. This has become particularly clear in the case of the Southlands project in the town of Tsawwassen, British Columbia, Canada, a proposed agricultural urbanism development described in great detail in the book that has yet to come to fruition. The Southlands project would have converted a 536-acre tract of former agricultural reserve land into an integrated residential, commercial, and food-growing community. The editors and their colleagues at HB Lanarc ran design charrettes (described in chapter 17) involving community visioning, site inventory and analysis, typology development, conceptual design,

\footnotetext{
${ }^{2}$ Canning, P., Charles, A., Huang, S., Polenske, K. R., \& Waters, A. (2010, March). Energy use in the U.S. food system (Economic Research Service report ERR-94). Washington, D.C.: U.S. Department of Agriculture.
} 
and site design. While the idea of a mixed-use agricultural urban community was well received early in the process, over time public opposition to developing the site has grown among those concerned about losing the land to housing and commercial buildings. On October 6, 2011, the local council received a new application for the project, triggering an additional public consultation process.
Whatever the fate of Southlands, Agricultural

Urbanism remains an intriguing and important idea that is likely to be adopted more broadly as communities seek to address issues of climate change, food security, and urban sustainability. For this reason, developers, architects, planners, and city officials will want to understand the concepts explored in this handbook and keep a copy on their shelves. 